\title{
A NURSE-LED SCHOOL-BASED SUN PROTECTION PROGRAMME IN TURKEY
}

\author{
Özüm Erkin, Ayla Bayık Temel \\ Department of Public Health Nursing, Faculty of Nursing, Ege University, Bornova-Izmir, Turkey
}

\begin{abstract}
SUMMARY
Objective: The aim of this study was to determine the effects of a nurse-led school-based sun protection programme in Turkey.

Methods: A randomized controlled trial was performed at two public schools between February and October 2014. Children with written consent from their parents were screened by nurses for skin type, and 80 children at moderate to high risk for skin cancer were included in the study. The sample was randomized by age, gender and skin type. Stratified and block randomizations were used. The participants were separated into an intervention group $(n=40)$ and control group $(n=40)$. Data were collected using a personal information form and two scales for sun protection behaviour and self-efficacy.

Results: In the intervention group, the pretest mean score for sun protection behaviour was $19.25 \pm 5.44$ and increased significantly in the posttest assessment $(33.05 \pm 4.23, p<0.001)$. Self-efficacy scores also increased significantly after the intervention (pretest $20.50 \pm 6.68$, posttest $35.85 \pm 4.70, p<0.001$ ). However, there were no significant increases in mean sun protection behaviour or self-efficacy scores in the control group $(p>0.05)$.
\end{abstract}

Conclusion: A nurse-led school-based sun protection programme effectively promoted children's self-efficacy and sun protection behaviour.

Key words: nurse, children, sun protection, skin cancer, school-based, Turkey

Address for correspondence: Ö. Erkin, Ege University, Faculty of Nursing, 35100 Bornova, İmir, Turkey. E-mail: ozum.erkin@gmail.com

https://doi.org/10.21101/cejph.a4975

\section{INTRODUCTION}

The rising incidence of skin cancer due to the harmful effects of ultraviolet (UV) radiation has become a major public health problem, and has been especially remarkable over the last 50 years in predominantly fair-skinned populations such as those in Australia, New Zealand, North America, and some western European countries (1). In Turkey, data from the Turkish Public Health Institute indicate that the incidence of melanoma is $2.1 / 100,000$ in men and 1.6/100,000 in women, and skin cancer is one of the 10 most common cancers (2).

There is a strong relation between lifelong exposure to sun, about $25 \%$ of exposure, the formation of melanoma and other skin cancers occur before the age of $18(3,4)$. The significant relationship between the extent of childhood UV exposure and subsequent skin cancer development in adulthood underlines the importance of promoting sun protection behaviour during childhood (3-5). A single blistering sunburn in childhood doubles an individual's risk of developing melanoma compared to someone with no history of sunburn (6-8). In view of this relationship, it is estimated that $80 \%$ of all skin cancers can be prevented by practicing proper sun protection behaviour during childhood and adolescence $(4,5)$.

Awareness of the detrimental effects of UV radiation on the skin and the 6-fold increase in melanoma and non-melanoma cancer incidence in the last 60-70 years have led to the development of prevention policies $(3,8-10)$. Children spend a large amount of their time outside the home engaging in outdoor activities such as games and sport activities (11-12). In particular, children are exposed to sunlight while they are in the school environment $(13,14)$. Considering the long hours spent at school and the role of sun exposure in childhood in skin cancer development, children should be protected from the sun at school (11, 12). Epidemiological studies show that sun protection behaviour acquired in early childhood is effective in cancer prevention (4, 6). Nurses are in an excellent position to promote sun protection behaviours because they work closely with schools, communities, and families. Through the implementation of nurse-led sun protection programmes, nurses can help raise awareness of sun protection behaviours among children and their families $(15,16)$. Nurses have an important role in protecting and promoting health within the scope of health services at school as part of primary prevention. Early diagnosis and prevention of skin cancer are also important for secondary prevention in the school environment. Teaching children the purpose and importance of sun protection can raise sun protection awareness even at young ages $(3,6)$. Recommended protective behaviours include using a sunscreen with an SPF of at least 30, wearing protective clothing, using sunglasses, avoiding the sun during the mid-day hours, avoiding artificial tanning facilities (solariums), and regularly performing skin self-examinations for changes in skin blemishes, spots and freckles every season (8).

In Miami, USA, where there are initiatives to develop prevention programmes and policies, a study in primary and secondary 
schools showed that school-based education programmes can achieve the national health objective of detecting and preventing threats such as skin cancer $(7,10)$. Training programmes emphasize prevention behaviours such as avoiding the sun during the mid-day hours, using sunglasses, wearing a hat, using a sunscreen, and avoiding solariums $(7,10)$. Due to its geographical location, some parts of Turkey are heavily exposed to sunlight for a substantial part of the year (17). In the western part of Turkey, including the province of Izmir, daytime lasts 7-11 hours for more than half of the year. Even in winter, this time does not fall below four hours. In summer, the UV index in Izmir is very high, even when assessed early in the day at approximately 9-10 a.m. (17). Therefore, sun protection behaviour in school children is an important public health education topic in Turkey. Gathering data about the behaviour of this group in Turkey is a vital first step in designing nursing interventions for sun protection behaviour. The aim of this study was to determine the effects of a nurse-led school-based sun protection programme in Turkey.

\section{MATERIALS AND METHODS}

\section{Design}

This randomized controlled trial was carried out in two public schools in İzmir, in western Turkey, between February and October 2014.

\section{Study Population}

The study population included 144 children. Children with written consent from their parents were screened by nurses for skin type. After screening, 96 children were found to have moderateto-high risk skin type (I, II, III) (18). Sixteen eligible children were excluded due to lack of parental consent. The study sample comprised 80 children based on a confidence interval of $95 \%$ and statistical power of $80 \%$ (19). The statistical analysis done at the end of the study showed that the study had statistical power of $73 \%$ based on a confidence interval of $95 \%$.

Children, who were 8-9 years old, were screened and considered at risk of skin cancer by a nurse based on a Fitzpatrick skin type between I and III, and whose parents gave written consent were included in the study (18). Children whose parents did not

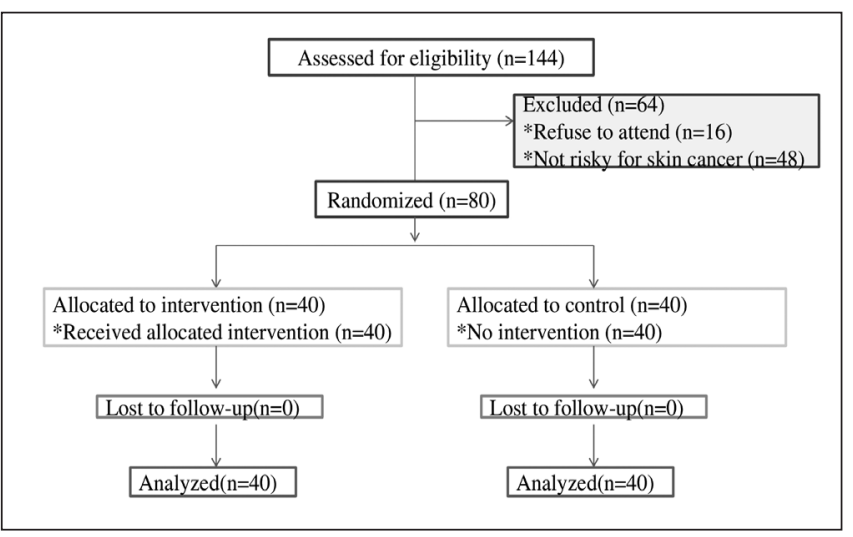

Fig. 1. CONSORT diagram of the study. give written informed consent and who had skin type IV, V and VI were excluded (18) (Fig. 1). Stratified and block randomizations were used for randomization. The schools were assigned into the intervention and the control groups by tossing a coin. Then, students in both groups were randomized in terms of their age, gender and skin type (19).

\section{Instruments}

The study was based on the transtheoretical model developed by Prochaska and Velicer. This model helps individuals make changes in their behaviour and provides guidance for health promotion programmes (20). Data were collected using a personal information form (including age, gender), Fitzpatrick skin type form (FSTP), sun protection behaviour scale (SPBS), and sun protection self-efficacy (SPSE). The FSTP was developed by Fitzpatrick and classifies individuals' skin type according to their response to sun exposure (i.e., the extent of burning and tanning) (18). The form includes 10 questions and was applied by a nurse for skin type screening in the present study. The SPBS measures the incidence of sun protection behaviour when outdoors for periods longer than 15 minutes. It is scored on a five-point scale ranging from 1 to 5 ( 1 - never, 2 - rarely, 3 - sometimes, 4 - often, and 5 - always) with $\alpha=0.86$ (21-23). The SPSE examines selfefficacy regarding protection from the sun. It is also scored on a five-point scale ( 1 - not at all confident, 2 - not very confident, 3 - moderately confident, 4 - very confident, and 5 - extremely confident) with $\alpha=0.84(20,22)$.

\section{Interventions}

The intervention group was offered a six-hour training programme based on the transtheoretical model in order to promote sun protection behaviour and to reinforce self-efficacy. The programme was prepared by the researchers in consideration of the SunSmart Program implemented in Australia, the SunWise School Program developed by the United States Environmental Protection Agency, and the sun protection guide issued by the Center for Disease Control and Prevention (13). The programme included various educational tools such as a sun protection story, activity book, PowerPoint presentations, cartoons, and puzzles $(24,25)$.

Refresher trainings were conducted 15 days, 1 month, and 2 months after the initial training $(9,26)$. Sun protection behaviour and self-efficacy of the children were evaluated at the beginning of the study and six months after the programme. As gifts to support their sun protection behaviour, the children were given an FDA-approved sunscreen with 50+ SPF, a white cotton shortsleeved T-shirt as protective clothing, sunglasses with 100\% UV protection, and a wide-brimmed hat. A nurse-led school-based sun protection programme is shown in Figure 2.

\section{Data Analysis}

Data were analyzed using Statistical Package for Social Sciences 17.0 software. The Shapiro-Wilk test showed that the data were not normally distributed. Descriptive characteristics were evaluated with frequencies, percentages, means, and standard deviations. The chi-square test was used to test homogeneity. Intragroup comparisons were made with Wilcoxon signed-rank 


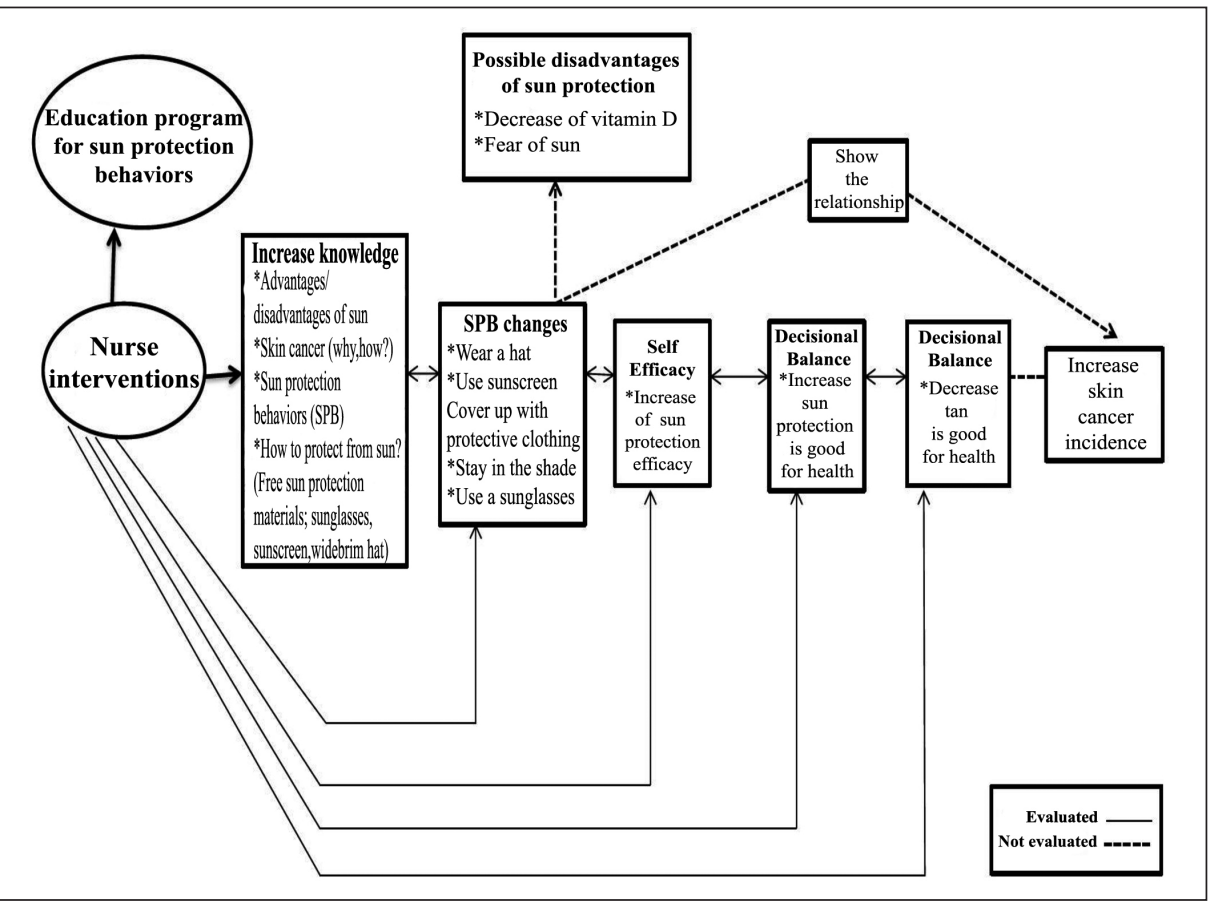

Fig. 2. A nurse-led school-based sun protection programme in Turkey.

test and intergroup comparisons were made with Mann-Whitney $\mathrm{U}$ test. A p value less than 0.05 was considered significant (19).

\section{Ethical Approval}

The study protocol was approved by the institutional review board of the Ege University Medical School. Written informed consent was obtained from parents of the children included in the study. After the study was completed, the nursing interventions offered to the intervention group were also given to the control group.

\section{RESULTS}

Characteristics of the intervention and control groups are shown in Table 1.
Mean scores for the SPBS and its subscales are shown in Table 2. Pretest and posttest mean SPBS scores were 19.25 \pm 5.44 and $33.05 \pm 4.23$ in the intervention group, and $20.52 \pm 6.44$ and $21.70 \pm 5.78$ in the control group, respectively (Table 2 ). The difference between the pretest and posttest values was significant in the intervention group $(\mathrm{Z}=-5.515, \mathrm{p}<0.001)$, but not in the control group $(Z=-1.681 \mathrm{p}=0.093)$. The difference between the intervention and control groups' SPBS scores was not significant pretest $(\mathrm{U}(\mathrm{z})=-1.262, \mathrm{p}=0.207)$ but was significant posttest $(\mathrm{U}(\mathrm{z})=-6.919, \mathrm{p}<0.001)$.

The mean SPSE scores in the intervention group were $20.50 \pm 6.68$ pretest and $35.85 \pm 4.70$ posttest (Table 3 ), which was a significant difference $(\mathrm{Z}=-5.517, \mathrm{p}<0.001)$. Mean pretest and posttest SPSE scores in the control group were $23.77 \pm 7.54$ and $24.17 \pm 6.75$ (Table 3 ), which was a nonsignificant difference $(\mathrm{Z}=-0.350, \mathrm{p}=0.726)$. However, the difference in mean SPSE score between the two groups was significant at both pretest

Table 1. Characteristic of intervention and control groups $(N=80)$

\begin{tabular}{|c|c|c|c|c|c|c|c|c|}
\hline \multirow{2}{*}{\multicolumn{2}{|c|}{ Characteristics }} & \multicolumn{2}{|c|}{ Intervention } & \multicolumn{2}{|c|}{ Control } & \multicolumn{2}{|c|}{ Total } & \multirow{2}{*}{$x^{2}, p$} \\
\hline & & $n$ & $\%$ & $n$ & $\%$ & $n$ & $\%$ & \\
\hline \multirow{2}{*}{ Age group } & 8 years & 30 & 75.0 & 28 & 70.0 & 58 & 72.5 & \multirow{2}{*}{$X^{2}=0.251, p=0.803$} \\
\hline & 9 years & 10 & 25.0 & 12 & 30.0 & 22 & 27.5 & \\
\hline \multirow{2}{*}{ Gender } & Female & 20 & 50.0 & 20 & 50.0 & 40 & 50.0 & \multirow{2}{*}{$x^{2}=0.000, p=1.000$} \\
\hline & Male & 20 & 50.0 & 20 & 50.0 & 40 & 50.0 & \\
\hline \multirow{3}{*}{ Skin type } & Type I & 9 & 22.5 & 9 & 22.5 & 18 & 22.5 & \multirow{3}{*}{$X^{2}=0.065, p=0.968$} \\
\hline & Type II & 16 & 40.0 & 17 & 42.5 & 33 & 41.2 & \\
\hline & Type III & 15 & 37.5 & 14 & 35.0 & 29 & 36.3 & \\
\hline \multicolumn{2}{|l|}{ Total } & 40 & 100 & 40 & 100 & 80 & 100 & \\
\hline
\end{tabular}

$x^{2}-$ Chi square test 
Table 2. Mean item and scale scores of sun protection behaviour scale $(N=80)$

\begin{tabular}{|l|c|c|c|c|}
\hline \multirow{2}{*}{ Items } & \multicolumn{2}{|c|}{ Intervention $(\mathrm{n}=40)$} & \multicolumn{2}{c|}{ Control $(\mathrm{n}=40)$} \\
\hline Stay in the shade & Pretest & Posttest & Pretest & Posttest \\
\cline { 2 - 5 } & Mean \pm SD & Mean \pm SD & Mean \pm SD & Mean \pm SD \\
\hline Avoid the sun during the mid-day hours & $2.82 \pm 0.78$ & $4.57 \pm 00.50$ & $2.85 \pm 1.07$ & $3.00 \pm 1.10$ \\
\hline Limit your exposure to the sun during the mid-day hours & $2.75 \pm 0.77$ & $4.60 \pm 0.50$ & $2.70 \pm 1.01$ & $2.85 \pm 1.00$ \\
\hline Use a sunscreen & $2.75 \pm 0.77$ & $4.35 \pm 1.07$ & $2.72 \pm 1.01$ & $2.92 \pm 0.94$ \\
\hline Use a sunscreen with an SPF of 15 or more on your face & $2.20 \pm 0.88$ & $3.87 \pm 0.96$ & $2.52 \pm 1.03$ & $2.62 \pm 0.95$ \\
\hline $\begin{array}{l}\text { Use a sunscreen with an SPF of 15 or more on all your sun } \\
\text { exposed areas }\end{array}$ & $2.20 \pm 0.88$ & $3.87 \pm 0.96$ & $2.55 \pm 1.10$ & $2.67 \pm 1.02$ \\
\hline Wear a hat & $2.20 \pm 0.88$ & $4.10 \pm 0.50$ & $2.47 \pm 1.03$ & $2.67 \pm 0.88$ \\
\hline Wear a hat with a wide brim & $2.22 \pm 0.94$ & $3.85 \pm 1.07$ & $2.57 \pm 0.84$ & $2.65 \pm 0.83$ \\
\hline Sun avoidance subscale & $2.10 \pm 0.90$ & $3.82 \pm 1.05$ & $2.12 \pm 1.10$ & $2.30 \pm 0.99$ \\
\hline Sunscreen subscale & $8.32 \pm 2.30$ & $13.52 \pm 1.90$ & $8.27 \pm 2.93$ & $8.77 \pm 2.82$ \\
\hline Hat use subscale & $6.60 \pm 2.64$ & $11.85 \pm 2.24$ & $7.55 \pm 3.07$ & $7.97 \pm 2.62$ \\
\hline Mean scale score & $4.32 \pm 1.81$ & $7.67 \pm 2.12$ & $4.70 \pm 1.66$ & $4.95 \pm 1.61$ \\
\hline
\end{tabular}

SD - Standard deviation

Table 3. Mean item and scale scores of sun protection self-efficacy $(N=80)$

\begin{tabular}{|l|c|c|c|c|}
\hline \multirow{2}{*}{$\begin{array}{l}\text { Please rate how confident you are that you would use sun } \\
\text { protection in each situation }\end{array}$} & Pretest & Posttest & Pretest & Posttest \\
\cline { 2 - 5 } & Mean \pm SD & Mean \pm SD & Mean \pm SD & Mean \pm SD \\
\hline $\begin{array}{l}\text { Use a sunscreen whenever you are out in the summer sun } \\
\text { for more than 15 minutes }\end{array}$ & $2.25 \pm 0.92$ & $3.95 \pm 0.74$ & $2.55 \pm 1.15$ & $2.57 \pm .90$ \\
\hline $\begin{array}{l}\text { Stay in the shade when all your friends are enjoying them- } \\
\text { selves in the sun }\end{array}$ & $2.50 \pm 1.01$ & $4.15 \pm 0.36$ & $2.90 \pm 1.21$ & $2.87 \pm 1.15$ \\
\hline Cover up with protective clothing even when it is hot outside & $2.47 \pm 0.87$ & $4.12 \pm 0.33$ & $2.75 \pm 1.19$ & $2.67 \pm 1.41$ \\
\hline $\begin{array}{l}\text { Use a sunscreen when no one else you are with is using } \\
\text { sunscreen }\end{array}$ & $2.30 \pm 0.82$ & $3.97 \pm 0.76$ & $2.60 \pm 1.19$ & $2.67 \pm 1.07$ \\
\hline $\begin{array}{l}\text { Avoid going outside in the summer sun during the midday } \\
\text { hours }\end{array}$ & $2.70 \pm 0.72$ & $4.20 \pm 0.40$ & $2.90 \pm 1.15$ & $2.82 \pm 1.23$ \\
\hline $\begin{array}{l}\text { Wear a hat with a wide brim even if you do not like how it } \\
\text { looks }\end{array}$ & $2.05 \pm 0.95$ & $3.77 \pm 1.09$ & $2.32 \pm .99$ & $2.42 \pm 1.03$ \\
\hline Use a sunscreen even if you do not like how it feels & $2.07 \pm 0.94$ & $3.95 \pm 0.74$ & $2.62 \pm 1.14$ & $2.72 \pm 1.01$ \\
\hline Use a sunscreen even if you want to get a tan & $2.07 \pm 0.94$ & $3.95 \pm 0.74$ & $2.55 \pm 1.28$ & $2.75 \pm 1.25$ \\
\hline Wear a hat even though no one else does & $2.07 \pm 0.99$ & $3.77 \pm 1.09$ & $2.57 \pm 0.98$ & $2.65 \pm 0.97$ \\
\hline Sun avoidance subscale & $7.67 \pm 2.39$ & $9.57 \pm 1.41$ & $8.55 \pm 2.85$ & $8.65 \pm 2.86$ \\
\hline Sunscreen use subscale & $8.70 \pm 3.50$ & $12.25 \pm 2.44$ & $10.32 \pm 4.17$ & $10.47 \pm 3.95$ \\
\hline Hat use subscale & $4.12 \pm 1.95$ & $5.67 \pm 1.73$ & $4.90 \pm 1.87$ & $4.92 \pm 1.67$ \\
\hline Mean scale score & $20.50 \pm 6.68$ & $35.85 \pm 4.70$ & $23.77 \pm 7.54$ & $24.17 \pm 6.75$ \\
\hline
\end{tabular}

SD - Standard deviation

assessment $(\mathrm{U}(\mathrm{z})=-2.481, \mathrm{p}=0.013)$ and posttest assessment $(\mathrm{U}(\mathrm{z})=-6.892, \mathrm{p}<0.001)$.

\section{DISCUSSION}

The SPBS is an effective means of evaluating individuals' sun protection behaviour. This scale is used to assess sun avoid- ance, sunscreen use, and hat use $(23,27)$. Before the training programme, both the children in the intervention group and those in the control group were found to rarely practice sun protection behaviour. However, in the posttest assessment, SPBS score significantly increased in the intervention group but remained unchanged in the control group. This demonstrated that the children in the intervention group exhibited sun protection behaviour often, while those in the control group continued to rarely exhibit 
this behaviour. In countries such as Australia, Sweden and the United States of America, the UV index is high in all seasons, and skin cancer prevention and sun safety programmes are applied in these countries $(9,16,26)$. School-based sun safety programmes have demonstrated the importance of school in acquiring behaviour protective against sunlight, and have also revealed the need for continuous and multiple interventions. In experimental studies, children in intervention groups displayed significant differences in terms of sun protection behaviour like avoidance, sunscreen use, and wearing hats and protective clothes compared to those in control groups $(13,14)$. Milne et al. determined that sun protection programmes implemented in Australia resulted in greater avoidance in the midday hours, less sun exposure, and increased sun protection behaviour like wearing protective clothing and staying in the shade (28). Gilaberte et al. from Spain also reported that staying in the shade and wearing protective clothing significantly increased in primary school students after an intervention (29). Similarly, Norman et al. found that school children got significantly higher SPBS scores after an intervention (30). Mays et al. also observed significant increases in children's sun protective behaviour such as using sunscreen, wearing protective clothing, staying in the shade, and avoiding harmful behaviour (31). Therefore, the results of the present study are consistent with the previous studies of schoolage children found in the literature.

The SPSE scale is used to evaluate an individual's confidence in adopting certain behavioural changes such as avoiding sunlight, using sunscreen, and wearing a hat $(21,23)$. Before nursing interventions, both the intervention group and the control group similarly marked "not very confident" about their sun protection behaviour. In the posttest, the children in the intervention group expressed feeling very confident, but the control group experienced no change in their confidence in their sun protection behaviour. Aygün and Ergün reported significant increases in adolescents' self-efficacy about their sun protection behaviour $(p<0.05)(21)$. De Vries et al. showed a significant relation between self-efficacy and wearing protective clothes (32). Buller et al. noted that sun protection self-efficacy significantly increased in students who received training compared to controls (33). Consistent with the literature, the present study also revealed a positive influence of nursing interventions on children's self-efficacy.

Limitations of this study include the self-reported data of the students, therefore, the results of the study cannot be generalized. The sun protection behaviour of children was also limited to the factors measured by the scales used in the study.

\section{CONCLUSION}

Authors determined that a nurse-led school-based sun protection programme was effective in increasing children's self-efficacy and sun protection behaviour. The results show that nursing interventions and the model used were useful and practical. The training programme used in this study can serve as a guide for health professionals to prevent health problems and promote healthy behaviours in school children. The results of this study will also facilitate the development of future national school health programmes in Turkey.

\section{Acknowledgements}

The authors would like to thank the Ege University Research Fund for funding this research and are grateful to the students for their participation in this study. The authors would also like to thank the participants' parents, whose active support of their children's sun protection behaviours contributed to the success of this project.

\section{Conflict of Interests}

None declared

\section{Authors' Contributions}

ÖE, AB: study design, data analysis, manuscript preparation; ÖE: data collection, drafting of manuscript; $\mathrm{AB}$ : critically reviewed the manuscript for final publication.

\section{REFERENCES}

1. Erdmann F, Lortet-Tieulent J, Schüz J, Zeeb H, Greinert R, Breitbart $\mathrm{EW}$, et al. International trends in the incidence of malignant melanoma 1953-2008 are recent generations at higher or lower risk? Int J Cancer. 2013 Jan 15;132(2):385-400

2. Gültekin M, Boztaş G, editors. Turkey cancer statistics [Internet]. Ankara: Ministry of Health of Turkey, Turkish National Public Health Agency; 2009 [cited 2016 Oct 22]. Available from: http://kanser.gov.tr/Dosya/ ca istatistik/2009kanseraporu.pdf. (In Turkish.)

3. Balk SJ; Council on Environmental Health; Section on Dermatology. Ultraviolet radiation: a hazard to children and adolescents. Pediatrics. 2011 Mar;127(3):e791-817.

4. Saraiya M, Glanz K, Briss PA, Nichols P, White C, Das D, et al. Interventions to prevent skin cancer by reducing exposure to ultraviolet radiation: a systematic review. Am J Prev Med. 2004 Dec;27(5):422-66.

5. Lovatt TJ, Lear JT, Bastrilles J, Wong C, Griffiths CE, Samarasinghe V, Roebuck J, at al. Associations between ultraviolet radiation, basal cell carcinoma site and histology, host characteristics, and rate of development of further tumors. J Am Acad Dermatol. 2005 Mar;52(3 Pt 1):468-73.

6. Maguire-Eisen M, Rothman K, Demierre MF. The ABCs of sun protection for children. Dermatol Nurs. 2005 Dec;17(6):419-22, 431-3; quiz 434.

7. McWhirter JM, Collins M, Bryant I, Wetton NM, Newton Bishop J. Evaluating 'Safe in the sun', a curriculum programme for primary schools. Health Educ Res. 2000 Apr;15(2):203-17.

8. NCCN Clinical practice guidelines in oncology. Basal cell and squamous cell skin cancers [Internet]. Fort Washington (PA): National Comprehensive Cancer Network; 2012 [cited 2016 Oct 22]. Available from: http:// pic2.cmt.com.cn/WebImages/Res/20130528/20130528_44232c3f-710548a1-8e30-b49a4cdca3e6.pdf.

9. SunSmart program [Internet]. Melbourne: Cancer Council Victoria; 2016 [cited 2016 Oct 22]. Available from: http://www.sunsmart.com.au.

10. Kirsner RS, Parker DF, Brathwaite N, Thomas A, Tejada F, Trapido EJ. Sun protection policies in Miami-Dade County public schools: opportunities for skin cancer prevention. Pediatr Dermatol. 2005 NovDec;22(6):513-9.

11. Glanz K, Saraiya M, Wechsler H; Centers for Disease Control and Prevention. Guidelines for school programs to prevent skin cancer. MMWR Recomm Rep. 2002 Apr 26;51(RR-4):1-18

12. Uysal A, Özsoy SA, Ergül Ş. Evaluating the skin cancer risks and sun protection practices of students. Ege J Med. 2004 May-Aug;43(2):95-9. (In Turkish.)

13. Geller AC, Rutsch L, Kenausis K, Selzer P, Zhang Z. Can an hour or two of sun protection education keep the sunburn away? Evaluation of the Environmental Protection Agency's Sunwise School Program. Environ Health. 2003 Nov 3;2(1):13.

14. Geller A, Rutsch L, Kenausis K, Zhang Z. Evaluation of the SunWise School Program. J Sch Nurs. 2003 Apr;19(2):93-9.

15. Balyac1 OE, Kostu N, Temel AB. Training program to raise consciousness among adolescents for protection against skin cancer through performance of skin self examination. Asian Pac J Cancer Prev. 2012;13(10):5011-7.

16. Buller DB, Buller MK, Beach B, Ertl G. Sunny days, healthy ways: evaluation of a skin cancer prevention curriculum for elementary school-aged children. J Am Acad Dermatol. 1996 Dec;35(6):911-22. 
17. Açar Y, Ekici M, Yagan S. Data analysis of ozone and ultraviolet radiation [Internet]. Ankara: Turkish State Meterological Service; 2012 [cited 2016 Oct 22]. Available from: http:/www.mgm.gov.tr/FILES/arastirma/ ozonuv/OveUveri-analizi.pdf. (In Turkish.)

18. Fiztpatrick TB. The validity and practicality of sun-reactive skin types I through VI. Arch Dermatol. 1988 Jun;124(6):869-71.

19. Polit DF. Statistics and data analysis for nursing research. 2 nd ed. New Jersey: Pearson; 2010.

20. Prochaska JO, Velicer WF. The transtheoretical model of health behavior change. Am J Health Promot. 1997 Sep-Oct;12(1):38-48.

21. Aygün Ö, Ergün A. Sun protection behaviors of adolescents: transtheoretical model study. Doctoral thesis. Istanbul: Marmara University; 2012. (In Turkish.)

22. Aygün Ö, Ergün A. Decisional balance and self-efficacy for sun protection: measurement among Turkish adolescents. Nurs Res. 2014 SepOct;63(5):309-19.

23. Maddock JE, Redding CA, Meier KS, Velicer WF, Prochaska JO. Development of transtheoretical model constructs for sun protection behaviors among adolescents. Ann Behav Med. 1998;20:Poster 208.

24. Erkin Ö. Sun protection novel book. 2nd ed. İstanbul: Özlem Publisher; 2015. (In Turkish.)

25. Erkin Ö. Sun protection activity book. 2nd ed. İstanbul: Özlem Publisher; 2015. (In Turkish.)

26. Sun Safety [Internet]. Washington, DC: United States Environmental Protection Agency; 2016 [cited 2016 Oct 22]. SunWise. Available from: http://www2.epa.gov/sunwise.

27. Aygün Ö, Ergün A. Validity and reliability of sun protection behavior scale among Turkish adolescent population. Asian Nurs Res (Korean Soc Nurs Sci). 2015 Sep;9(3):235-42.
28. Milne E, Jacoby P, Giles-Corti B, Cross D, Johnston R, English DR. The impact of the kidskin sun protection intervention on summer suntan and reported sun exposure: was it sustained? Prev Med. 2006 Jan;42(1):14-20.

29. Gilaberte Y, Alonso JP, Teruel MP, Granizo C, Gállego J. Evaluation of a health promotion intervention for skin cancer prevention in Spain: the SalSano program. Health Promot Int. 2008 Sep;23(3):209-19.

30. Norman GJ, Adams MA, Calfas KJ, Covin J, Sallis JF, Rossi JS, et al. A randomized trial of a multicomponent intervention for adolescent sun protection behaviors. Arch Pediatr Adolesc Med. 2007 Feb;161(2):14652.

31. Mays D, Black JD, Mosher RB, Heinly A, Shad AT, Tercyak KP. Efficacy of the Survivor Health and Resilience Education (SHARE) program to improve bone health behaviors among adolescent's survivors of childhood cancer. Ann Behav Med. 2011 Aug;42(1):91-8.

32. De Vries H, Willems KD, Mesters I, Reubsaet A. Skin cancer prevention behaviours during summer holidays in 14 and 18-year-old Belgian adolescents. Eur J Cancer Prev. 2006 Oct;15(5):431-8.

33. Buller DB, Reynolds K, Yaroch A, Cutter GR, Hines JM, Geno CR, et al. Effects of the Sunny Days, Healthy Ways curriculum on students in grades 6 to 8. Am J Prev Med. 2006 Jan;30(1):13-22.

Received November 9, 2016 Accepted in revised form November 30, 2017 